\title{
IAMJ
}

INTERNATIONAL AYURVEDIC MEDICAL JOURNAL

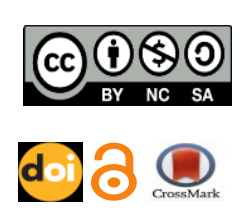

Research Article

ISSN: 23205091

Impact Factor: 5.34

\section{ANALYTICAL STUDY OF PIPPALYADI ANJANA: AN AYURVEDIC FORMULATION}

\author{
$\underline{\text { Sharma Gunjan }}^{1}, \underline{\text { Akanksha }}^{2} \underline{\text { Prasad Renu }}^{3}, \underline{\text { Kumar Arun }}^{4}$
}

${ }^{1}$ HOD \& Professor Dept. Of Shalakya Tantra, Rishikul Campus, UAU, Haridwar, Uttarakhand, India

${ }^{2}$ Pg Scholar Dept. Of Shalakya Tantra, Rishikul Campus, UAU, Haridwar, Uttarakhand, India

${ }^{3}$ Associate Professor Dept. Of Shalakya Tantra, Rishikul Campus, UAU, Haridwar, Uttarakhand, India

${ }^{4}$ Assistant Professor Dept. Of Shalakya Tantra, Rishikul Campus, UAU, Haridwar, Uttarakhand, India

Corresponding Author: akanksha0729@gmail.com

\section{https://doi.org/ $10.46607 /$ iamj08092020}

(Published online: September 2020)

Open Access

(C) International Ayurvedic Medical Journal, India 2020

Article Received: 22/08/2020 - Peer Reviewed: 27/08/2020 - Accepted for Publication: 13/09/2020

(A) Check for updates

\begin{abstract}
Pippalyadi Anjana is an Ayurvedic topical formulation mentioned in Ayurvedic classic. The formulation is believed to cure ocular ailments such as Arma, Timira, Kaach, Arjuna. According to Acharya Yogratnakar this Anjana can be used to eradicate all the ocular disorders if prepared appropriately. It can be the best option among all Anjanas from which the eye diseases can't be appeared. Keeping all these points in view this study has been undertaken with the aim to modify Pippalayadi Anjana into ointment form and to develop the physicochemical profile of the final product. Anjana was prepared in the form of Ghan Satva Kalpana and the Laksha and Saindhav was added then mixed with Siktha of cow ghee and emulsified bee wax for attaining the final product.

Materials and Method: The prepared drug was evaluated for organoleptic study, physiochemical study, $\mathrm{pH}$ value and the product were subjected for microbial contamination test, it was tested in analytical laboratory and results were documented.

Result: The result shows the organoleptic character and sterility.

Conclusion: Pippalyadi Anjana was prepared by following the method prescribed in Yogratnakar. This paper presents the analytical study of the formulation.
\end{abstract}

Keywords: Pippalyadi Anjana, Organoleptic study, Analytical study. 
In Ayurvedic classical texts administration of potent formulation in the form of Anjana is used in ocular disorders which are classified by Acharya Shushruta into Churnanjana (fine powder), Gutikanjana (tablet rubbed in appropriate solution) and Rasanjana (semi solid form). ${ }^{(1)}$ Pippalyadi Anjana is one of such formulation mentioned by Yogratnakar in his text which comprises of Pippali, Triphala, Laksha, Lodhra, Saindhava and Bhringraja. It is believed to have Pharmacological action over ocular disorders such as Timira, Kaach, Arma, Kandu, Shukra Roga, Arjuna rog. ${ }^{(2)}$ Almost all the drugs in the formulation are having either Rasayana or Chakshushya properties. Triphala acts as a best Rasayana and Chakshushya ${ }^{(3)}$ i.e. it relieves the eye strain and strengthen the visual functions. Pippali has been stated as "Kaphaanilaghni" and Rasayana by Acharya Sushruta ${ }^{(4)}$. Acharya Bhavmishra called Bhringraj as "Netraartinut" (5) i.e. pacifies all ocular disorders. According to Acharya Bhavmishra Lodhra is having Chakshushya and "Kaphapittaaghna"(6) properties. He also described Laksha as "Kaphapittasranut" and Vranropaka (7). Saindhava reduces the vitiated Tridoshas and also acts as a Chakshushya Rasayana. ${ }^{(8)}$ The analytical study of this Anjana formulation may serve as a supporting literature for future studies for maintaining standard quality of formulation.

\section{Aim and Objectives}

1. To analyse the organoleptic character of the drug.
2. To find out the sterility test and physicochemical properties of Pippalyadi Anjana formulation prepared by classical methods.

\section{Materials and Methods}

Collection of Raw drug: The raw drugs for the study were acquired from the Hans Pharmacy Premnagar Ashram, Haridwar Uttarakhand Figure 1-8. The final product of Pippalyadi Anjana was prepared in the Hansa Pharmacy Premnagar Ashram, Haridwar Uttarakhand. Figure 9-12.

\section{Method of preparation of Pippalyadi Anjana}

The Pippalyadi Anjana was prepared by classical method of Ghana satva. For Ghana satva all six herbal drugs i.e Pippali (Piper longum), Amalaki (Emblica officinalis), Haritiki (Terminalia chebula), Vibhitaki (Terminalia bellirica), Laksha (laccifera lacca), Lodhra (Symplocos racemosa), Saindhava (Rock salt), Bhringraja (Eclipta alba) were taken in equal amount (1 kg each) and decoction was made in eight times of water till it remain $1 / 4^{\text {th }}$ of it, then that $1 / 4^{\text {th }}$ part of decoction was filtered and again boiled till it become thicker. After that all that Ghan satva was dried into tray drier at temperature $35-40^{\circ} \mathrm{C}$ and then powdered.

Now, Saindhav and Laksha were added in $1 / 6^{\text {th }}$ part of above powdered drug after filtered it in 120 No sieve mesh and mixed well. In the end Go ghrit and emulsified Bee wax were made by Siktha Kalpana in the ratio of 3:1 was taken as base ingredient and then the whole powder was mixed in Siktha in the ratio of 2:1.

Table 1: Pippalyadi Anjana and their proportion

\begin{tabular}{|l|l|l|l|l|}
\hline Drug & Latin Name & Family & Part use & Ratio \\
\hline Pippali & Piper longum & Piperaceae & Fruit & $1000 \mathrm{gm}$ \\
\hline Amalaki & Emblica officinalis & Euphorbiaceae & Fruit & $1000 \mathrm{gm}$ \\
\hline Haritaki & Terminalia chebula & Combretaceae & Fruit & $1000 \mathrm{gm}$ \\
\hline Vibhitaki & Terminalia bellerica & Combretaceae & Fruit & $1000 \mathrm{gm}$ \\
\hline Lodhra & Symplocos racemosa & Symplocaceae & Bark & $1000 \mathrm{gm}$ \\
\hline Bhringraj & Eclipta alba & Compositae & Whole plant & $1000 \mathrm{gm}$ \\
\hline Saindhav lavana & - & - & - & $1 / 6^{\text {th }}$ of all herbal Ghan \\
\hline Laksha & Laccifer lacca & Lacciferidae & Resin & $1 / 6^{\text {th }}$ of all herbal Ghan \\
\hline
\end{tabular}

Analytical Study: Prepared final product i.e. Pippalyadi Anjana was analyzed by applying various analytical parameters.
Organoleptic study or Physical characterization description: Organoleptic characteristics for various sensory characters like colour, taste, odour, etc. was carefully noted down. 
Table 2: Physical characterization Description

\begin{tabular}{|l|l|}
\hline Appearance & A Blackish coloured semisolid mass \\
\hline Colour & Dark brown \\
\hline Odour & Characteristic \\
\hline Taste & Characteristic \\
\hline
\end{tabular}

\section{Physicochemical Analysis}

Physicochemical analysis such as Loss on drying at $105^{\circ}$ was carried out. Loss on drying of final product was in normal range given in (Table 3 ). Along this the microbial limit test and heavy metal test were carried out. Results of these tests were obtained within the normal range (table4-5)

Table 3: Physicochemical analysis of Pippalyadi Anjana

\begin{tabular}{|l|l|}
\hline Parameters & Pippalyadi Anjana \\
\hline Loss on drying & 10.01 \\
\hline
\end{tabular}

Table 4: Microbial Limit Test

Total bacterial count (cfu/g)

Total fungal count 10

E.coli

Salmonella sp.

P.aeruginosa

S. aureus

10

Absent

Absent

Absent

Absent

Table 5: Heavy Metals Test

\begin{tabular}{|l|l|}
\hline Lead $(\mathrm{Pb}) \mathrm{ppm}$ & 4.6 \\
\hline Arsenic $(\mathrm{As}) \mathrm{ppm}$ & 0.78 \\
\hline Cadmium $(\mathrm{Cd}) \mathrm{ppm}$ & 0.14 \\
\hline Mercury $(\mathrm{Hg})$ ppm & 0.28 \\
\hline
\end{tabular}

pH Value: $\mathrm{pH}$ was determined by using Digital $\mathrm{pH}$ meter. One gram of ointment was dissolved in $100 \mathrm{ml}$ of distilled water and kept for 2 hours and the measurement of $\mathrm{pH}$ was 5.65 which is weakly acidic.

Sterility Test: Sterility test was done by the method mentioned under IP 2007, Vol-2, which shows that the drug was tested, was sterile.

\section{RESULTS AND DISCUSSION}

Pharmacognostical evaluation showed that organoleptic characters of the sample were dark brown in colour, blackish semi solid in appearance and characteristic odour and taste.

The physicochemical parameters play an important role in the standardization of formulation. According to present study, the purity of Anjana is assessed by $\mathrm{pH}$ value, microbiological study, Heavy metal test and sterility test. The loss on drying at $105^{\circ} \mathrm{C}$ was 10.01 $\mathrm{w} / \mathrm{w}$. The $\mathrm{pH}$ from $10 \% \mathrm{w} / \mathrm{v}$ solution revealed that $\mathrm{pH}$ of formulation was comparable and slightly acidic. This may be because of acidic salts present in the crude drugs used for preparation of formulation.

The microbiological study of Pippalyadi Anjana showed that the quality of Anjana in standard condition. The microorganisms (bacteria \& fungal) found within normal limit. The quantity of Heavy metal is within normal limit came in heavy metal test. And the sterility test showed the Pippalyadi Anjana is sterile and the test for Aflatoxin was absent. 


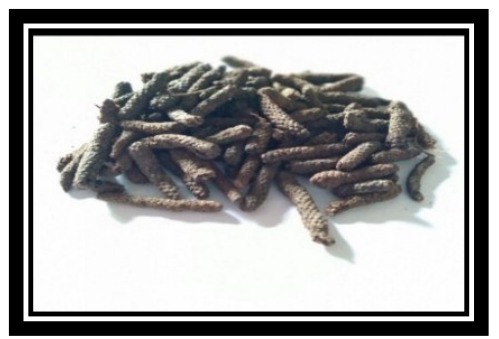

Figure 1: Piper longum

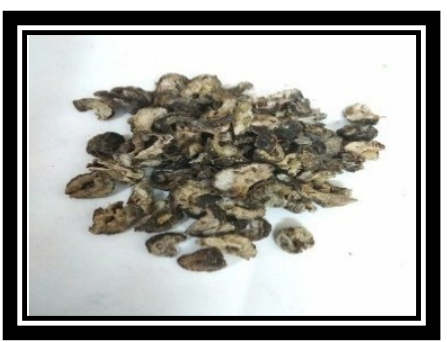

Figure 2: Emblica officinalis Figure 3: Terminalia chebula

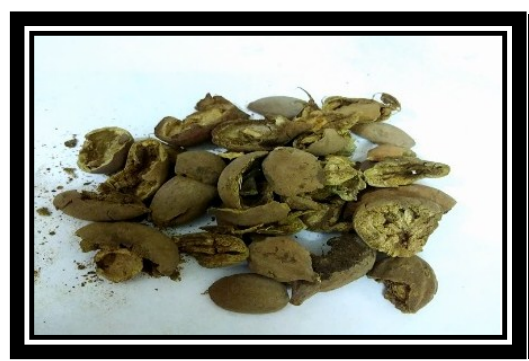

Figure 4: Terminalia bellirica

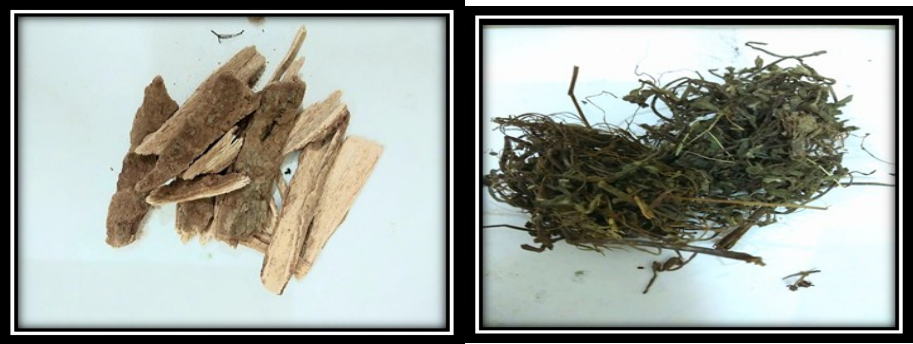

Figure 5: Symplocos racemosa Figure 6: Eclipta alba

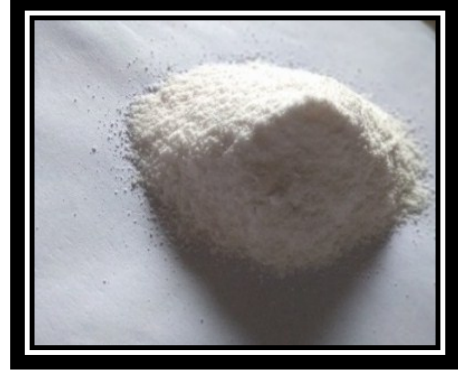

Figure 7: Saindhava

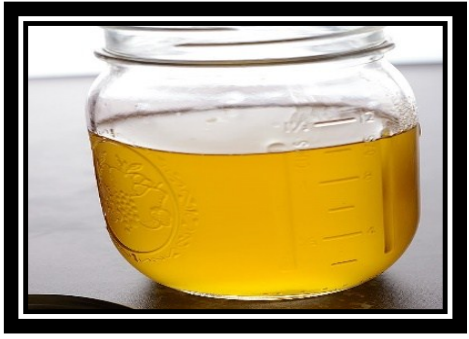

Figure 9: Cow Ghee

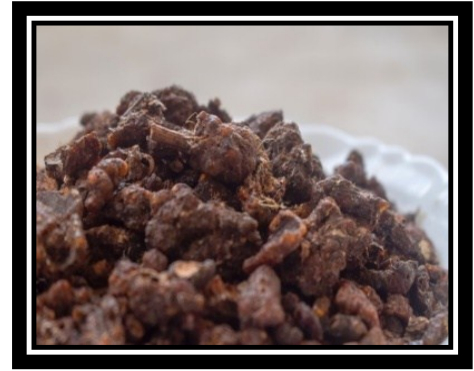

Figure 8.a: Lacciera lacca

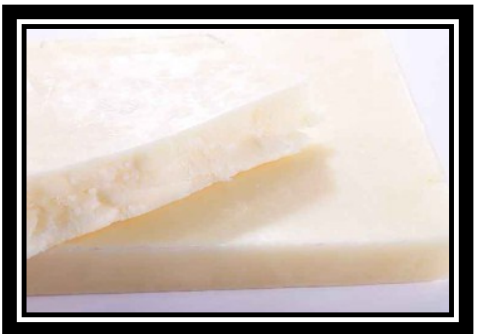

Figure 10: Emulsified Bee wax

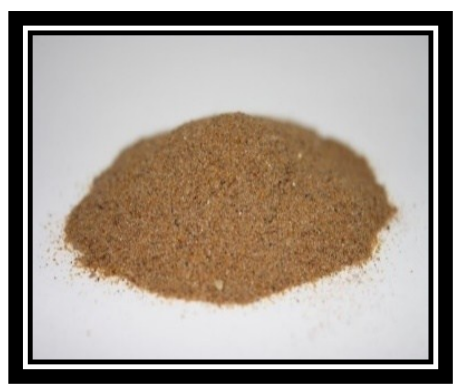

Figure 8.b: Laccifera lacca (Powdered)

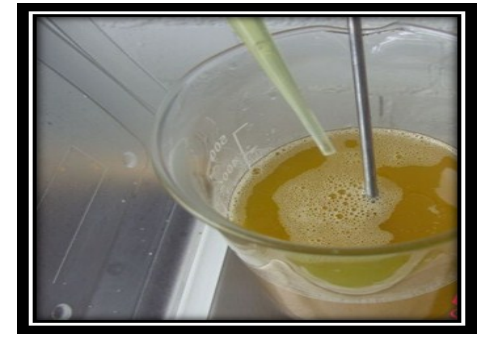

Figure 11: Siktha 

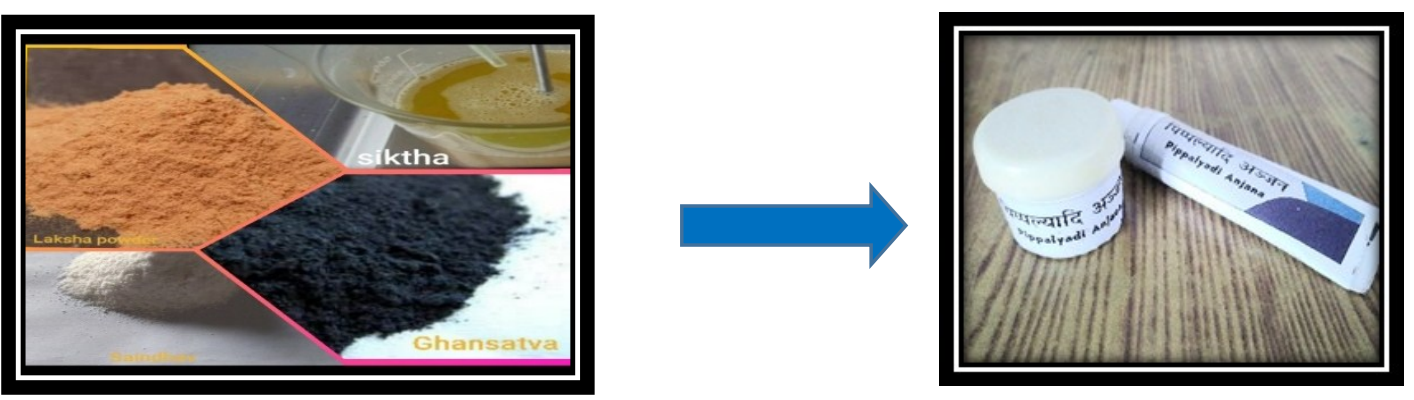

Figure 12: Final product (Pippalyadi Anjana)

\section{CONCLUSION}

Pharmacognostical and physiochemical evaluation of Pippalyadi Anjana illustrated the specific characteristics of this preparation. It is the first time when pharmaceutical and analytical profile of Pippalyadi Anja$n a$ was established. On the basis of microscopic features, the physiochemical profile and microbial limit tests are essential parameters for the quality of formulation. All parameters in this preparation were found within normal limits. On that basis, the present study on Pippalyadi Anjana may be used for standardisation and quality evaluation.

\section{REFERENCES}

1. Shastri Ambikadutt, editor of Ayurveda Tattva Sandipika, Hindi Commentary on Susruta Samhita, Chaukhamba Sanskrit Sansthan, Varanasi Reprint, 2011; Uttartantra 18/52.): 98 .

2. Shastri Laxmipati, Yogratanakar vidyotini hindi $2^{\text {nd }}$ Edition, Varanasi Chaukhamba Sanskrit Sansthana, 2021 Sanvatsara, Netrarogadhikar Pg.No.369

3. Shastri Ambikadutt, editor of Ayurveda Tattva Sandipika, Hindi Commentary on Susruta Samhita, Chaukhamba Sanskrit Sansthan, Varanasi Reprint, 2011; sutrasthana 38/57: p188

4. Shastri Ambikadutt, editor of Ayurveda Tattva Sandipika, Hindi Commentary on Susruta Samhita, Chaukhamba Sanskrit Sansthan, Varanasi Reprint, 2011; sutrasthana 46/223, p 261.

5. Prof. Chunekar K.C, Bhavaprakash Nighantu, Chaukhamba Sanskrit Sansthan, Varanasi. 2013 guduchyadi varga (241) p-414.

6. Prof. Chunekar K.C, Bhavaprakash Nighantu, Chaukhamba Sanskrit Sansthan, Varanasi. 2013 Haritkyadi varga (216), p-124.
7. Prof. Chunekar K.C, Bhavaprakash Nighantu, Chaukhamba Sanskrit Sansthan, Varanasi. 2013 Haritkyadi varga (194-195), p-110.

8. Pandit Kashinath Shastri \& Dr. Gorakhnath Chaturvedi, Hindi commentary on Charaka Samhita of Agnivesha revised by Charaka and Dridbala, Chaukhamba Sanskrit Sansthan Varanasi, 2013 sutrasthan 27/300, p561.

\section{Source of Support: Nil \\ Conflict of Interest: None Declared}

How to cite this URL: Akanksha et al: Analytical Study Of Pippalyadi Anjana: An Ayurvedic Formulation. International Ayurvedic Medical Journal \{online\} 2020 \{cited September, $2020\}$ Available from: http://www.iamj.in/posts/images/upload/4363 4367.pdf 